\title{
Потенциал для ненадлежащего использования биологии
}

\section{Филиппа Лентзос}

Департамент социальных наук, здоровья и медицины, Кингс Колледж, Лондон http://kcl.ac.uk

\begin{abstract}
Резюме: Международное сообщество установило четкие красные линии, ограничивающие использование биологии для наращивания национальной мощи вооружений. Прогресс в биологических науках и биомедицине, однако, подверг существенной эрозии технологические барьеры на пути приобретения и использования биологического оружия. В этой статье дано описание современных научных тенденций и сделан анализ их влияния на сферу безопасности. Более подробно рассмотрены три новые области исследований, которые располагают особенно высоким потенциалом для ненадлежащего использования: потенциально пандемические патогены, синтетическая биология и нейробиология. В статье обоснована точка зрения, что необходимо продолжение усилий на многостороннем, национальном и научном уровнях для укрепления красных линий и для создания ответственной науки.
\end{abstract}

Ключевые слова: Биологическое оружие, потенциально пандемические патогены, синтетическая биология, нейробиология, разоружение, биобезопасность, ответственная наука.

\section{Ненадлежащее использование биологии}

Международное сообщество провело четкие красные линии, ограничивающие ненадлежащее использование биологии. Краеугольными камнями в отношение биологии в нормах ведения войны являются Конвенция о биологическом оружии (КБО) и Женевский протокол. В сочетании они запрещают создание, производство, хранение и использование биологического оружия. Подписанные соответственно в 1972 и 1925, эти два договора интегральным образом включили в международные нормы 
сочетание юридических, дипломатических и политических элементов, которое все труднее разобрать, игнорировать или обойти.

Научный прогресс в биологии и биомедицине, однако, в большой степени разрушает технологические барьеры на пути приобретения и использования биологического оружия. В этой статье описаны современные тенденции в биологических науках и проанализированы их последствия для безопасности. Более подробно рассмотрены три области исследований, которые располагают особенно большим потенциалом для ненадлежащего применения биологии. Требуется продолжение усилий на многостороннем, национальном и научном уровне для укрепления красных линий. Критически важными областями, требующими усиления, являются (1) международные нормативные рамки, регулирующие биологическое оружие, (2) процедура КБО для мониторинга биологических наук и технологий, (3) нормы прозрачности и публичной подотчетности.

\section{Тенденции в биологических науках}

Есть четыре часто упоминаемые тенденции в биологических науках, которые связаны с безопасностью: ${ }^{1}$

1. Ускорение прогресса в биологических науках. Быстрый прогресс на многих фронтах в науках о жизни порождает проблему отслеживания и оценки того, какое значение имеет этот прогресс для разработки биологического оружия. Трудно решить какие области следует подвергать мониторингу, прогнозировать какие новые сочетания прорывов последуют из прогресса в множестве направлениях и как расширить квалификацию, необходимую для оценки этих новых развитий.

2. Усиливающаяся конвергенция биологии и биомедицины с химией, инжинирингом, математикой, компьютерными науками и информационной теорией. Такое развитие ситуации, к примеру, позволяет, как химический синтез биологических молекул, так и биологический синтез химикатов. Когда компоненты существенно отличны от существующих биологических систем, или когда неор-

1 "The Biological and Toxin Weapon Trends Symposium," IAP Global Network of Science Academies conference, 13-15 September 2015; n "Assessing the Implications of Advances in Science and Technology for the BTW 2016," IAP Global Security Working Group Meeting, 16 September 2015, Polish Academy of Sciences, Warsaw, Poland (резюме доступно на iapbwg.pan.pl); Organisation for the Prohibition of Chemical Weapons, Convergence of Chemistry and Biology: Report of the Scientific Advisory Board's Temporary Working Group (The Hague: OPCW, 2014); National Research Council, Life Sciences and Related Fields: Trends Relevant to the Biological Weapons Convention (Washington, DC: National Academies Press, 2011); "The Biological Weapon Convention Seventh Review Conference," 5-22 December 2011, Geneva, "New Scientific and Technological Developments Relevant to the Convention" (BWC/CONF.VII/INF.3). 
ганические материалы имитируют биологические функции и следовательно имеют биологическое влияние, механизмы действия данного оружия могут не быть чисто "биологическими» или «химическими» - размывая сферы действий Конвенций о биологическом и химическом оружии.

3. Ускорение диффузии потенциала в сфере биологии и биомедицины по всему свету, в частности в такие развивающиеся экономики, как Китай и Индия. Так же имеет место расширение международного сотрудничества, не только между исследователями в развитых в научном отношении странах и между исследователями в развитых и развивающихся странах, но и в рамках региональных сетей и во все большей степени между исследователями развивающихся стран.

4. Увеличение открытости науки в результате использования таких новых инструментов, как википедия, блоги и микроблоги, изменяющие способы сбора, обработки, распространения и осуществления доступа к информации; и облегченный доступ благодаря сообществам любителей, популяризации науки и образовательным играм к аппаратуре для работы с биологическими материалами в области наук о жизни. Многие мультинациональные поставщики сейчас производят наборы, содержащие реагенты, энзимы и пошаговые инструкции для усваивания основных лабораторных технологий, которые используют ученые биологи, в том числе для экспрессии, очистки, обнаружения и анализа нуклеиновых кислот и протеинов. Предлагаются коммерческие услуги по секвенированию, синтезу ДНК и протеинов, созданию микроматриц, масс-спектрометрическому анализу и т.д. Наличие малогабаритных, автоматизированных и более простых в использовании биоинструментов так же облегчает проведение лабораторных исследований.

\section{Влияние на потенциал для создания биологического оружия}

Существующие тенденции в биологических науках облегчают разработку биологического оружия. В одной недавней оценке глобальной сети научных академий сделано заключение, что технологические барьеры на пути приобретения и использования биологического оружия за последние пять лет подверглись существенной эрозии. ${ }^{2}$

Сейчас проще обзавестись естественными и синтетическими патогенами и усилить и оптимизировать их для конкретных целей, в том числе и для использования в качестве биологического оружия. Стало легче производить и биологические агенты. Такое критически важное лабораторное оборудование, как сосуды для осуществления реакций (в том числе и те, которые попадают в нынешние списки оборудования, подлежащего кон-

2 "The Biological and Toxin Weapon Trends Symposium." 
тролю) сейчас можно изготовить используя технологию 3D печати. Расширенное использование биосинтеза и основанного на биопроцессах производства, матриц и «биофермерства» увеличило скорость и выход производства биоагентов. Кроме того, уменьшились необходимые для биологического производства пространство и ресурсы и физические размеры производственного оборудования тоже существенно снизились. Для тиражирования сейчас необходимы меньше пространства и меньше времени и такую грязную деятельность стало легче скрывать. Прогресс в нанотехнологиях и аэробиологии, наряду с использованием химических кофакторов для расширения понимания и формул способов улучшения абсорбции в желудочно-кишечном тракте делают распыление и доставку бактериологических агентов легче, а повышенная антимикробная сопротивляемость усложняет введение профилактических средств. В двух словах, глобальная сеть научных академий утверждает, что научный прогресс «может облегчить почти каждый шаг в программах разработки биологического оружия». ${ }^{3}$

Хотя риски маломасштабных биотеррористических нападений существуют и они реальны, вероятность того, что научный прогресс будет использоваться для “усиления» таких атак относительно невысокая - большинство самых передовых технологий дорогостоящи и их сложно приобрести и успешно реализовать. ${ }^{4}$ Наоборот, наибольшая опасность для безопасности от злонамеренного использования прогресса в биологических науках исходит из возможности осуществления изощренных биологических нападений со стороны таких профессиональных и хорошо обеспеченных ресурсами институций, как вооруженные силы. ${ }^{5}$ Это подтверждается историей разработки биологического оружия и случаев биотерроризма. ${ }^{6}$

Международное сообщество решено - через КБО и Женевский протокол - предпринять меры предосторожности против того, чтобы научные достижения не использовались ненадлежащим образом. За время существования КБО не было случая использования биологического оружия государственным субъектом и эксперты единодушны в том, что потенциал

Там же.

4 Filippa Lentzos, "The Risk of Bioweapons Use: Considering the Evidence Base," BioSocieties 9:1 (2014): 84-93; Catherine Jefferson, Filippa Lentzos, and Claire Marris, "Synthetic Biology and Biosecurity: Challenging the 'Myths'," Frontiers in Public Health 2:115, http://dx.doi.org/10.3389/fpubh.2014.00115; "The Biological and Toxin Weapon Trends Symposium."

5 Iris Hunger, et al., "The Future of Biothreat Governance," in Biological Threats in the $21^{\text {st }}$ Century, ed. Filippa Lentzos (London: Imperial College Press, forthcoming); Gigi Kwik Gronvall, "The Threat of Misuse," in Biological Threats in the $21^{\text {st }}$ Century; Lentzos, "The Risk of Bioweapons Use"; Jefferson, "Synthetic Biology and Biosecurity."

6 Lentzos, Biological Threats in the $21^{\text {st }}$ Century. 
для его использования государствами очень небольшой. ${ }^{7}$ В пользу такого вывода указывается на несколько причин: биологическое оружие не считается “хорошим» оружием; производить изощренное и надежное биологическое оружие трудно, а его использование политически неприемлемо поскольку международные нормы - сведенные главным образом в КБО являются очень жесткими.

Однако, хотя законы против биологического оружия являются очень строгими и потенциальное его использование государством маловероятно, считать, что угроза использования биологического оружия государствами полностью отсутствует очень опасно. Нельзя полагать, что биологическое оружие не будет применено в будущем т.е. вероятность его использования не равна нулю. Хотя военное использование биологического оружия в двадцать первом веке рассматривалось главным образом на стратегическом уровне, а в качестве средств доставки рассматривались бомбы, ракеты или рассеивание самолетами на большой площади, есть ученые и военные планировщики, которые придерживаются других идей допускают тактическое использование и саботажи с использованием биологического оружия. Сегодня мы должны думать о биологическом оружии совсем не так, как в двадцатом веке. Биологическое оружие, например, можно сравнивать с кибероружием в смысле, что жертва может знать, что подверглась нападению, но не знать с чьей стороны, или даже не знать, или быть в состоянии доказать, что вообще подверглась нападению - вопрос кто несет ответственность даже может быть не задан. Молчаливый и невидимый способ воздействия биологического оружия может сделать их очень эффективным средством для ослабления легитимности вражеских режимов среди собственного населения, или просто для их загружения дополнительными проблемами. В «идеальном случае» было бы возможно на самом деле избавиться от неугодного режима без того, чтобы кто-то заподозрил нечестную игру.

Хотя использование биологии не будет иметь военное значение во всех современных конфликтах, возможность того, что оно могло бы иметь значение в небольшом наборе конфликтов, наряду с размыванием технологических барьеров на пути его приобретения и использования, придает императивный характер тому, что угрозе его применения государствами уделяется большая часть коллективного внимания и разрабатываются эффективные превентивные меры.

\section{Новые области исследований, которые имеют большой потен-} циал для злонамеренного использования

Предпринимаются разные усилия, в частности в Соединенных Штатах, для идентификации биологических исследований, которые имеют наибольший

7 Hunger, "The Future of Biothreat Governance"; Kwik Gronvall, "The Threat of Misuse"; Lentzos, "The Risk of Bioweapons Use." 
потенциал ненадлежащего применения. ${ }^{8}$ В число таких идентифицированных примеров «исследований двойного назначения» входят эксперименты, которые увеличивают возможности: для изменения патогенности, вирулентности, специфики приемника, передаваемости, устойчивости против лекарств или способности преодолевать иммунитет приемника против патогенов; синтеза патогенов и токсинов без культивации микроорганизмов или использования естественных источников для них; идентификации новых механизмов для подрыва нормального функционирования людей, животных и растений и разработки новых средств доставки биологических агентов и токсинов. Первые высокотехнологические эксперименты, которые породили опасения были направлены на усиление смертоносности мышиной оспы, синтезирование полиовирусов с нуля и восстановление исчезнувшего вируса гриппа от 1918 года. ${ }^{9}$ В последнее время, опасения вызывают целые сферы биологических исследований. В их число входят потенциально пандемические патогены, синтетическая биология и нейробиология.

\section{Потенциально пандемические патогены}

Вирусология привлекла внимание сообщества, занимающегося безопасностью, в 2011 году, когда стало известным, что две ведущих лаборатории по гриппу, под руководством Рона Фуше и Йошихиро Каваока, проводили эксперименты для определения того может ли вирус птичьего гриппа H5N1 стать легко передаваемым между млекопитающими, оставаясь сильно вирулентным. H5N1 не передается легко от человека к человеку, но он приводит к смерти более 50\% зараженных. Фуше и Каваока боялись, что H5N1 может стать легко передаваемым между млекопитающими, сохраняя высокую вирулентность, и вирусологи опасались, что государства не воспринимали эту угрозу достаточно серьезно. Летом 2011 года, обе группы осуществили передачу вируса между хорьками в качестве примера и установили, что на самом деле возможно появление вируса, передавае-

8 K примеру: National Research Council, Biotechnology Research in an Age of Terrorism (Washington, DC: National Academies Press, 2004); National Science Advisory Board for Biosecurity, Proposed Framework for the Oversight of Dual-Use Life Sciences Research (Washington: NSABB, 2007); US Government Policy for Oversight of Life Sciences Dual Use Research of Concern (March 2012); and US Government Policy for Institutional Oversight of Life Sciences Dual Use Research of Concern (September 2014), доступно на http://osp.od.nih.gov/office-biotechnology-activities/ biosecurity/dual-use-research-concern.

9 Ronald J. Jackson, et al., "Expression of Mouse Interleukin-4 by a Recombinant Ectromelia Virus Suppresses Cytolytic Lymphocyte Responses and Overcomes Genetic Resistance to Mousepox," Journal of Virology 75 (2001): 1205-1210; Eckard Wimmer, "The Test-tube Synthesis of a Chemical Called Poliovirus. The Simple Synthesis of a Virus Has Far-reaching Societal Implications," The European Molecular Biology Organization Reports - Special Issue 7 (2006): S3-S9; Terrence M. Tumpey, et al., "Characterization of the Reconstructed 1918 Spanish Influenza Pandemic Virus," Science 310 (2005): 77-80. 
мого по воздуху. Иными словами, то, что они разработали в своих лабораториях, было новой, более заразной разновидностью вируса птичьего гриппа, которая могла передаваться между людьми и другими млекопитающими.

Несколько более подробно развитие этой истории описывает Кэтлин Фогель. ${ }^{10}$ В двух словах, Фуше послал свой доклад в престижный журнал Science; Каваока предпочел Nature. В сентябре 2011, Фуше обнародовал свои выводы на научной конференции в Мальте: его мутировавший вирус передавался воздушно-капельным путем так же легко, как вирус сезонного гриппа. Публично Фуше комментировал, что «это очень опасный вирус». ${ }^{11}$ Организация, финансировавшая эти исследования, Национальный институт здоровья (НИЗ), была обеспокоена последствиями для безопасности в случае, если результаты буду опубликованы: не сумеют ли биотеррористы (или национальные вооруженные силы) принять на вооружение такую технологию "усиленной функции» для увеличения патогенности и передаваемости вирусов? НИЗ попросил Национальный научный консультативный совет по биобезопасности (ННКСББ), консультативный государственный орган, осуществляющий мониторинг исследований двойного назначения в науках о жизни, рассмотреть обе публикации. В конце ноября 2011 года, ННКСББ рекомендовал, чтобы общие выводы, освещающие новые результаты, были опубликованы, но чтобы рукопись не включала раздел с подробным описанием методов проведения экспериментов. ${ }^{12}$ Это первый случай, когда ННКСББ рекомендовал наложить ограничения на научные публикации в сфере наук о жизни.

Последствия этого эксперимента для безопасности были широко отражены в средствах массовой информации. The New York Times опубликовал редакционную статью с категорическим заголовком «Искусственно вызванный конец света», в которой утверждалось, что модифицированный вирус гриппа может привести к смерти десятков или сотен миллионов людей, если по неосторожности или в результате краже выйдет из стен

${ }^{10}$ Kathleen M. Vogel, “Expert Knowledge in Intelligence Assessments: Bird Flu and Bioterrorism," International Security 38 (Winter 2013-2014): 39-71.

11 Цитировано в Katherine Harmon, "What Really Happened in Malta This September When Contagious Bird Flu Was First Announced," Scientific American (blog), 30 September 2011, http://blogs.scientificamerican.com/observations/what-reallyhappened-in-malta-this-september-when-contagious-bird-flu-was-first-announced/. В конце сентября, в статье в New Scientist, еженедельный журнал о новостях в науке и технологиях, впервые рассказал, что модифицированный вирус H5N1 Фуше оказался смертельным для хорьков в эксперименте - смотри Дебора Маккензи, "Five Easy Mutations to Make Bird Flu a Lethal Pandemic," New Scientist, 26 September 2011, www.newscientist.com/ article/mg21128314-600-five-easymutations-to-make-bird-flu-a-lethal-pandemic/.

12 U.S. Department of Health and Human Services, "Press Statement on the NSABB Review of H5N1 Research," NIH News, 20 December 2011, http://www.nih.gov/news/ health/dec2011/od-20.htm. 
лаборатории. Сторонники исследований приобретенных функций, с другой стороны, утверждали, что такие исследования позволяют понять механизм передачи вируса гриппа и могут помочь ученым в сфере общественного здоровья идентифицировать предстоящие пандемии гриппа и приготовить вакцины.

В январе 2012 года, группа известных вирусологов написала ННКСББ письмо с просьбой пересмотреть свои рекомендации. ННКСББ опубликовал объяснение и аргументы в защиту своего решения одновременно в Nature и Science. Основной причиной для этой беспрецедентной редакции было то, что «публикация подробного описания этих экспериментов даст некоторым людям, организациям или государствам информацию, которая поможет им разработать подобные передаваемые между млекопитающими вирусы гриппа A/H5N1 для злонамеренных целей». К середине февраля 2012 года, Всемирная организация здоровья (ВОЗ) провела технические консультации по экспериментам Фуше и Каваока. ${ }^{13}$ На консультациях присутствовали и представили новые данные оба этих ученых. Встреча ВОЗ пришла к общему пониманию, что в интересах общества необходим временный мораторий. Фуше и Каваока должны были отредактировать свои рукописи с новыми деталями и передать их ННКСББ для повторного рассмотрения.

Фуше отступил. Он заявил, что мутировавший вирус, созданный его группой не был смертельным при вдыхании хорьками и не будет распространяться как «лесной пожар» по воздуху; наоборот, распространение затруднено. Он так же сказал, что большинство хорьков, зараженные вирусом, переносили болезнь легко и ни один из них не умер. Он пояснил, однако, что мутировавший вирус, полученный воздушным путем на самом деле вызывает тяжелое заболевание при впрыскивании в очень больших концентрациях в нижнюю область дыхательных путей хорьков.

В итоге, ННКСББ рекомендовал опубликовать отредактированную работу Каваока полностью, но некоторые из членов совета все еще имели сомнения относительно работы Фуше. Они чувствовали, что эти публикации могут «непосредственно и напрямую способствовать» терроризму (и разработке биологического оружия» и являются «весьма полной поваренной книгой» для нанесения ущерба. В мае 2012 года работа Каваока была опубликована в Nature. Работа Фуше последовала этому примеру и была опубликована в Science в июне 2012.

В соответствие с добровольным мораторием, работа по потенциально пандемическим патогенам была возобновлена в 2013 году многими уче-

${ }^{13}$ World Health Organization, "Technical Consultation on H5N1 Research Issues Consensus Points," 16-17 February 2012, http://www.who.int/influenza/human animal_interface/consensus_points/en/index.html; and World Health Organization, "Public Health, Influenza Experts Agree H5N1 Research Critical but Extend Delay," 17 February 2012, www.who.int/mediacentre/news/releases/2012/h5n1_research_ 20120217/en/index.html. 
ными в множестве лабораториях, причем биологическим агентам добавлялись новые свойства и создавались модифицированные варианты вирусов, которые не существовали в природе. Через небольшой промежуток времени, новые работы по синтезированным человеком H5N1 и других опасных разновидностей гриппа возобновили опасения относительно потенциально пандемических патогенов, созданных в лабораториях - в некоторой мере из-за серии лабораторных инцидентов и нарушений безопасности в НИЗ и у Центров контроля и превенции болезней (ЦКПБ) появились вопросы о безопасности в лабораториях с повышенной защитой. 17 октября 2014 года вмешалось правительство США, наложив мораторий на финансирование экспериментов с потенциально пандемическими патогенами, обусловленный расширенным процессом изучения вопроса, который все еще не закончен. ${ }^{14}$

\section{Синтетическая биология}

Многие рассматривают противоречия, касающиеся потенциально пандемических патогенов, как тестовой пример того, что случиться, когда новоявленная область «синтетической биологии» достигнет зрелости. Синтетическая биология стремится превратиться в инжиниринговую биологию, т.е. «проектировать и производить части, новые устройства и системы на биологической основе, а так же переделывать существующие, естественные биологические системы». ${ }^{15}$ Амбиции и темп развития синтетической биологии порождают некоторые озабоченности, связанные с безопасностью. Некоторые из этих опасений оправданы, другие в меньшей степени. $^{16}$

Одним из основных страхов в политическом дискурсе и дискурсе безопасности в этом плане является то, что синтетическая биология облегчает создание опасных патогенов с нуля. Предполагается, что хорошо известные биологические части легко получить из открытых онлайн реестров и затем собрать в генетические схемы, устройства и системы, которые надежно будут выполнять заданные функции в живых организмах, причем это могут сделать люди без специальной квалификации и вне стен профессиональных научных институций. Такой нарратив опирается на некоторых бытующих заблуждениях, касающихся синтетической биологии.

14 "U.S. Government Gain-of-Function Deliberative Process and Research Funding Pause on Selected Gain-of-Function Research Involving Influenza, MERS, and SARS Viruses," 17 October 2014, http://www.phe.gov/s3/dualuse/Documents/gain-offunction.pdf (accessed 20 January 2016).

15 The Royal Academy of Engineering, Synthetic Biology: Scope, Applications and Implications (London: The Royal Academy of Engineering, 2009).

16 Filippa Lentzos, Catherine Jefferson, and Claire Marris, "The Myths (and Realities) of Synthetic Bioweapons," The Bulletin of Atomic Scientists, 18 September 2014, http://thebulletin.org/myths-and-realities-synthetic-bioweapons7626; Jefferson, et al., "Synthetic Biology and Biosecurity." 
Подобная картина не отражает ситуацию с которой сталкиваются люди без специальной подготовки, которые работают вне профессиональных научных институтов, не отражает даже текущую реальность в академических или коммерческих научных лабораториях: академические и коммерческие исследователи все еще борются с каждым этапом процесса стандартизации и механизации. Более, чем десятилетие с начала, перевод демонстрационных дизайнов в практические приложения все еще остается главным вызовом. Как недавно было отмечено в обзорных публикациях по прогрессу в синтетической биологии, «Осуществить синтетическую часть несложно, ограничивающей является биологическая часть». ${ }^{17}$ Однако, даже если и инжиниринговые подходы, предлагаемые синтетической биологией, делают процесс более систематическим и воспроизводимым, необходимость в специальных умениях не исчезает, да и все аспекты работы не становятся более легкими. Кроме того, «более легкие» не означает «легкие». Хорошую аналогию дает авиационное машиностроение: самолеты строят из большого числа стандартизированных частей систематическим путем, но это не означает, что каждый человек может построить самолет, поднять его в воздух и использовать его для коммерческих перевозок. Подобным образом, прогресс в синтетической биологии не делает более легким для каждого обыкновенного человека производить биологические системы, в том числе и опасные.

Это приводит нас ко второму опасению, поднимаемому в политическом и связанном с безопасностью дискурсах: синтетическая биология уничтожает границу между экспертами и не-экспертами. Иными словами, развитие сообщества «сделай сам» биологии (СС био), наряду с удешевлением и аутсорсингом ДНК синтеза, может сделать более легким для террористов приобретение основных материалов для создания агентов, представляющих биологическую угрозу. Однако связь между синтетической биологией и СС био, и сложность обычно осуществляемых экспериментов, сильно преувеличены. Биологами в СС био обычно является широкий круг участников с разным уровнем квалификации, начиная от совершенных новичков без предыстории в биологии и кончая опытными учеными, которые проводят эксперименты в свое свободное время. Некоторые из СС биологов работают в домашних лабораториях, оборудованных ежедневными домашними инструментами и бывшим в употреблении лабораторным оборудованием, купленным онлайн; большинство осуществляют свои эксперименты в лабораториях сообщества или в «хакерских берлогах». Исследования научной практики в лабораториях сообщества показывают с какими проблемами сталкиваются биологи любители, пытающиеся проводить даже рудиментарные биологические эксперименты. В частности, у любителей нет доступа к информации общего пользования, находящейся в

17 Timothy S. Gardner, et al., "Synthetic Biology: From Hype to Impact," Trends in Biotechnology 31:3 (2013): 123-125, quoted in Nature Reviews Microbiology 12:5 (2014): 309. 
распоряжении институциональных исследователей, что подчеркивает важность локальных, специальных знаний и культуры лабораторной практики.

Синтез ДНК является одной из ключевых технологий синтетической биологии. В данное время есть несколько коммерческие компании, которые предоставляют услуги, связанные с синтезом ДНК так, что процесс может быть передан внешнему подрядчику: клиент может заказать ДНК последовательность онлайн и получить синтезированный ДНК материал по почте в течение нескольких дней или недель. Цены, запрашиваемые этими компаниями, существенно уменьшились за последние 20 лет и сейчас эта услуг доступна широкому кругу игроков. Это привело к тривиальному заключению, что сегодня дешево и легко можно получить синтезированную версию любой желаемой ДНК последовательности.

Есть, однако, несколько проблем, которые надо брать в расчет, когда оценивается потенциал для злонамеренного использования, к которому может привести возможность для недорогостоящего секвенирования ДНК. Во-первых, заказать онлайн полную геномную последовательность малых вирусов (или больших бактерий) в настоящее время попросту невозможно. Альтернативный вариант, заказывать короткие ДНК последовательности и затем собирать из них геном, требует специальную квалификацию, опыта и оборудования, которые имеются в наличии в академических лабораториях, но не являются легко доступными для любителей, работающих дома. Как было отмечено ННКСББ, хотя «технология для синтезирования ДНК является готовым, доступным, прямым и основным инструментом, используемым в современных биологических исследованиях ... наука конструирования и экспрессии вирусов в лаборатории несколько сложнее и представляет собой почти искусство. Именно последовательность лабораторных процедур синтезирования ДНК является фактором, ограничивающим создание вирусов из генетического материала». ${ }^{18}$ И снова, биологическая часть, а не синтетическая, является сложной и синтез ДНК требует длительной подготовки в области молекулярно-биологических технологий, например лигирования и клонирования, в том числе и практический опыт, который нельзя свести к «рецептам, оборудованию и инфраструктуре». ${ }^{19}$

Третьим, часто озвучиваемым опасением является то, что синтетическая биология может позволить конструирование радикально новых патогенов, может усилить вирулентность или передаваемость известных патогенов, создавая новые опасные агенты. Опять же, это не просто. Часто цитируются эксперименты с мышиной оспой и птичьим гриппом (H5N1) в качестве примеров того, как можно создать опасные новые патогены. Од-

18 National Science Advisory Board for Biosecurity (NSABB), Addressing Biosecurity Concerns Related to the Synthesis of Select Agents (Bethesda, MD: National Institutes of Health, 2006), 4.

19 Kathleen Vogel, "Bioweapons Proliferation: Where Science Studies and Public Policy Collide," Social Studies of Science 36:5 (2006): 676. 
нако, в оценках этой опасности обычно не учитывается бросающийся в глаза факт: в этих двух экспериментах исследователи в действительности не сконструировали патогены. Что касается H5N1, исследователи некоторое время пытались спроектировать передаваемый воздушным путем вирус, но безуспешно. Эксперимент с хорьками был задуман как альтернативный подход, чтобы проверить могут ли естественные мутации создать передаваемый по воздуху вариант. Исследователи не оказывали влияние на инициированные конкретные мутации. В эксперименте с мышиной оспой, исследователи встроили ген для интерлевкина-4 в вирус мышиной оспы, чтобы вызвать бесплодность у мышей и служил инфекционным контрацептивом для борьбы с грызунами. Результат - измененный вирус стал смертельным для мышей -не был спрогнозирован учеными; это не было запроектировано.

Кроме того, некоторые из уроков обширной советской программы использования биоагентов в качестве оружия указывают на то, что улучшение характеристик, желательных в контексте программы создания биооружия, например вирулентности, всегда происходит за счет ухудшения других, в равной мере желаемых свойств, например трансмиссивности или устойчивости. Плейотропные эффекты - это когда один ген оказывает влияние на более, чем одну характеристику, и на генетическую нестабильность - являются обычными для микроорганизмов. Хотя было бы упрощением утверждать, что повышенная трансмиссивность всегда связана с ослабленной вирулентностью, очень часто именно так обстоит дело с разновидностями, созданными в лабораториях. Как отмечали и другие комментаторы,
Чтобы создать ... искусственный патоген, способному синтетическому биологу нужно собрать комплексы генов, которые работая в координа- ции, позволят микробу заразить человека-приемника и вызвать его бо- лезнь или смерть. Проектирование заразных организмов, такие, чтобы передавались от человека к человеку, еще более трудно. Синтетический патоген должен быть снабжен механизмами блокирования иммунной защиты приемника, свойство, которое натуральные патогены приоб- рели за тысячелетия эволюции. С учетом этих обескураживающих тех- нических препятствий, угроза синтетического "супер-патогена» выгля- дит преувеличенной, по крайней мере, на обозримое будущее. ${ }^{20}$

В итоге можно сказать, что вероятно в ближайшем будущем синтетическая биология будет в состоянии создавать опасные вирусы с нуля. Однако, синтетическая биология уменьшает требования к умениям в науке, но не до такой степени, чтобы люди без специальной подготовки, работающие вне профессиональных научных институций, смогут собирать биологические части в цепи, устройства и системы, которые надежно будут вы-

20 Jonathan B. Tucker and Raymond A. Zilinskas, "The Promise and Perils of Synthetic Biology," The New Atlantis 25 (2006): 38. 
полнят желаемые функции в живых организмах, и даже профессионалам трудно создавать радикально новые патогены или синтетические «суперпатогены». Следовательно, риски ненадлежащего использования синтетической биологии проистекают не от биотеррористов, а от таких профессиональных и хорошо обеспеченных ресурсами институций, как национальные вооруженные силы. $^{21}$

Последние числа по тенденциям в финансировании исследований по синтетической биологии в США показывают, что две третьи из инвестированных в 2014 году 200 миллионов долларов пришли из Министерства обороны (MO) или его исследовательского агентства DARPA. ${ }^{22}$ Аналитики в других странах, занимающиеся этой тематикой, могут рассматривать обширный поток военного финансирования как угрозу с точки зрения международной безопасности. МО только что объявило, что на исследования по биообороне в 2014 году были затрачены 655 миллионов долларов; таким образом финансирование исследований в сфере синтетической биологии составляет одну пятую всего бюджета на биооборону. ${ }^{23}$

В других странах финансирование этих исследований так же быстро увеличивается. В 2014 году инвестиции Объединенного Королевства и Европейской комиссией в синтетическую биологию составили 30 процентов от евро-американского финансирования синтетической биологии. ${ }^{24}$ Часть этого европейского финансирования так же связано с обороной. К примеру, в Объединенном Королевстве, которое тратит на исследования по синтетической биологии в два раза больше, чем Европейская комиссия, эта область определена Министерством обороны как одна из пяти новых технологий, имеющих наибольший потенциал для национальной безопасности. Критически важным является то, чтобы военные исследования в этой области оставались настолько прозрачными, насколько это возможно, для гарантирования уверенности, что тонкая линия между позволенной оборонной деятельностью и недозволенной работой в интересах нападения не будет размыта.

21 Jefferson, et al., "Synthetic Biology and Biosecurity."

22 "US Trends in Synthetic Biology Research Funding" (Washington DC: Wilson Center, 2015), доступно на http://www.synbioproject.org/site/assets/files/1386/final_web_ print_sept2015.pdf (по состоянию на 20 января 2016).

23 US Department of State, Confidence-Building Measure Return Covering 2014: Convention on the Prohibition of the Development, Production and Stockpiling of Bacteriological (Biological) and Toxin Weapons and on their Destruction, submitted to the United Nations on 15 April 2015, доступно на www.unog.ch/80256EDD006B8954/ (httpAssets)/4631533639F1D34AC1257E380046511B/\$file/BWC_CBM_2015_USA_P ublic.pdf (по состоянию на 20 января 2016).

24 US Trends in Synthetic Biology. 


\section{Нейробиология}

Еще одной новой областью с высоким потенциалом злонамеренного использования является нейробиология. ${ }^{25}$ Заинтересованность военных в нейробиологии в основном связан с работой по усилению оперативных способностей национальных сил и ослаблению способностей противника.

Есть разные способы, которыми нейробиология обеспечивает преимущество в военном контексте. ${ }^{26}$ Один из них состоит в использовании нейрофармацевтических агентов для улучшения таких когнитивных функций, как восприятие, внимание, обучение, память, язык, мышление, планирование и принятие решений. Имеется значительный военный интерес в когнитивном усовершенствовании. Считается, что модафинил - открытый французскими учеными в 1970-х и с тех пор лицензированный как стандартное лечение при нарколепсии, но для которого было доказано, что он улучшает работу памяти и исполнительное функционирование людей лишенных сна - был использован французской армией в Ираке в начале 1990-х для борьбы с боевой усталостью и военно-воздушными силами США в 2003 для улучшения бдительности и концентрации во время длительных полетов. ${ }^{27}$ Что заинтересованность военных в поддержании и улучшении функционирования мозга остается, показывает большое число проектов DARPA, направленных на достижение этой цели. ${ }^{28}$ Нейробиология была идентифицирована Министерством обороны Объединенного Королевства как важная и быстроразвивающаяся область с потенциалом, имеющим отношение к обороне и безопасности. ${ }^{29}$

Ухудшение способностей противника методами нейробиологии было сфокусировано на разработке выводящих из строя биохимических агентов, или так называемых не летальных оружиях. Средства, делающих людей нетрудоспособными, в принципе воздействуют на центральную нервную систему с целью снизить бдительность и, если доза увеличивается, вызвать успокоение, сон, наркотическое состояние и смерть; их следует отличать от таких средств для борьбы с беспорядками, как слезоточивый газ, которые вызывают местное раздражение глаз, кожи и дыхательных путей, и давно используются полицейскими силами во всем мире.

25 National Research Council, Emerging Cognitive Neuroscience and Related Technologies (Washington, DC: National Academies Press, 2008); The Royal Society, Neuroscience, Conflict and Security (London: The Royal Society, 2012), http://royalsociety.org/ policy/projects/brain-waves/society-policy/ (по состоянию на 20 января 2016); Tim Requarth, "This is Your Brain. This Is Your Brain as a Weapon," Foreign Policy, 14 September 2015, http://foreignpolicy.com/2015/09/14/this-is-your-brain-this-is-yourbrain-as-a-weapon-darpa-dual-use-neuroscience/ (accessed 20 January 2016).

Royal Society, Neuroscience, Conflict and Security, Chapter 4 "Performance Enhancement."

27 Там же.

28 Там же, 6 и 35-36.

29 Там же. 
Несмотря на международную Конвенцию о химическом оружии (КХO) от 1993 года, есть признаки, что ряд стран продолжает проявлять интерес к приводящим к недееспособности биохимическим агентам. КХO запрещает использование токсических химических препаратов во время войны, но не мешает государствам использовать такие химические вещества, как «слезоточивый газ», для охраны правопорядка и для борьбы с внутренними беспорядками. Хотя набор дозволенных токсических веществ ограничен по типу и количеству для нужд охраны правопорядка, некоторые государства считают это исключение в интересах охраны правопорядка распространяется и на приводящие к недееспособности химические препараты.

Озабоченность заинтересованностью государств в химических препаратах, приводящих к недееспособности, усилилась после случая реального их использования в Российской Федерации в октябре 2002 года. ${ }^{30}$ Группа вооруженных чеченских сепаратистов захватила театр на Дубровке в Москве и взяла в заложники приблизительно 800 человек. Они требовали вывод российских войск из Чечни и угрожали, что убьют заложников если их требования не будут выполнены. Российские части специального назначения распылили приводящий к обездвиживанию химический препарат - предположительно смесь производных синтетического опиата фентанил - через вентиляционную систему театра приводя как заложников, так и террористов в бессознание. Сразу после этого спецназовцы ворвались внутрь, застрелили всех похитителей и положили конец захвату театра. 129 из заложников погибли от воздействия химического препарата и многие получили серьезные травмы с долгосрочными последствиями. Отказ российских сил особого назначения раскрыть природу приводящего в бессознание агента помешало медперсоналу скорой помощи реагировать адекватно. Есть так же признаки, что после этого события Российская Федерация продолжает исследования по обездвиживающим биохимическим веществам. ${ }^{31}$ США так же проявляет долгосрочный интерес к приводящим в бессознание биохимическим агентам. ${ }^{32}$

Как и в сферу синтетической биологии, текущие инвестиции в область нейробиологии весьма значительны. Финансируемый Европейской комиссией проект «Человеческий мозг», инициированный в 2013 году, оценивается в $€ 1190$ миллионов на период в десять лет. ${ }^{33}$ Эквивалентный проект в США, инициатива BRAIN, была запущена тоже в 2013 году как публичночастное партнерство с бюджетом в \$100 миллионов на 2014 бюджетный

30 Neal Davison, "Non-Lethal" Weapons (London: Palgrave Macmillan, 2009), 12-13.

31 Royal Society, Neuroscience, Conflict and Security.

32 Там же.

33 The Human Brain Project: A Report to the European Commission (Lausanne: The HBPPS Consortium, 2012), https://www.humanbrainproject.eu/documents/10180/ 17648/TheHBPReport_LR.pdf (по состоянию на 20 января 2016). 
год. Приблизительно половина финансирования в эту сферу в США приходит из МO и DARPA. ${ }^{34}$

Развитие исследований по анестетикам и нейрофармакологическим лекарствам, в сочетании с усовершенствованием методов доставки лекарств, делают точное манипулирование нейробилогических функций все более используемым и есть опасения относительно рисков, которым подвергают международный запрет химического оружия приводящие к недееспособности вещества. ${ }^{35}$ Биорегуляторы являются специализированными химическими препаратами, которые переносят сигналы от мозга к остальному телу, между нейронами или внутри клеток, и модулируют функции целевой клетки или органа. Это естественные биохимические компаунды (гормоны, или сигнальные факторы), которые управляют такими жизненно важными гомеостатическими системами, как температура, сон, давление крови, частота сердцебиения и иммунная реакция. Однако, хотя они встречаются в организме в низких концентрациях, они могут быть исключительно токсичными при более высоких концентрациях или если их молекулярная структура будет изменена. Хотя многие биорегуляторы склонны к нестабильности в аэрозольной форме и быстро расщепляются энзимами в организме, можно синтезировать их искусственные варианты. В последнее время отмечается существенный прогресс в in vitro синтезе биорегуляторов для фармацевтических целей. Аэрозольная технология так же развивается высокими темпами и уже используется при лечении болезней для эффективного введения лекарств путем вдыхания. ${ }^{36}$ Дозирующие аэрозольные ингаляторы, порошковые ингаляторы и распылители используются для доставки лекарств напрямую в легкие, способствуя их быстрой абсорбции в крови. Прогресс исследований в области методов доставки лекарств или вакцин путем ингаляции может так же дать потенциальные возможности для доставки биорегуляторов. Благодаря достижениям в нейробиологии в конце концов станет возможно создавать модифицированные биорегуляторы, которые можно будет рассеивать над большими скоплениями людей и которые будут преодолевать барьер между кровью и мозгом, вызывая состояния сна, замешательства, безмятежности, страха, зависимости или агрессии. ${ }^{37}$

Европейский проект «Человеческий мозг» явным образом заявил, что не будет принимать финансирование от военных или разрабатывать приложения для военных целей. ${ }^{38}$ В нем так же есть «этическая и социальная» часть, которая «занимается изучением социальных, этических и философ-

\footnotetext{
Там же.

35 Royal Society, Neuroscience, Conflict and Security, 49-50.

36 Там же, 50.

37 Там же.

38 https://www.humanbrainproject.eu/documents/10180/538356/HBP_FPA_PRINT_ 29-07-14.pdf (по состоянию на 20 января 2016).
} 
ских последствий проекта, способствует привлечению к участию субъектов принимающих решения и широкой публики, поощряет ответственные исследования и инновации путем повышения социальной и этической осведомленности среди партнеров проекта и гарантирует, что проект соответствует юридическим и этическим нормам». ${ }^{39}$ В настоящее время подобных мероприятий в американской программе нет.

\section{Стимулирование ответственной науки}

Пандемические патогены, синтетическая биология и нейробиология являются тремя областями биологии, которые располагают особенно высоким потенциалом для злонамеренного использования. Существуют, конечно, и другие области исследований, имеющие потенциал ненадлежащего использования. Хотя КБО и Женевский протокол обеспечивают законодательную и нормативную рамку для предотвращения такого использования, нужны дальнейшие усилия на многостороннем, национальном и научном уровне для укрепления красных линий, ограничивающих ненадлежащее использование биологии. Критическими областями, в которых необходимы дополнительные усилия, являются (1) международноправовая база, регулирующая биологическое оружие, (2) процедура КБО по мониторингу науки и технологий, и (3) нормы прозрачности и публичной подотчетности.

\section{1. Укрепление международно-правовой рамки, регулирующей биоло- гическое оружие}

Статья IV КБО обязывает стран-членов запрещать и предотвращать деятельность, связанную с биологическим оружием. Это означает, что они не просто обязаны реагировать на запрещенную деятельность, но и должны не допускать ее ведения. Важным механизмом принуждения к выполнению является криминализация этой деятельности.

Криминализация такой деятельности на международном уровне, в качестве международного преступления или военного преступления, дает возможность для применения самих строгих и эффективных мер для возложения индивидуальной ответственности за нарушения международного законодательства. Ни использование биологии для производства оружия, ни использование биологического оружия достаточно комплексно криминализированы в Римском статуте Международного уголовного суда (МУС). ${ }^{40}$ Использование «ядов или отравленных оружий», запрет на что

39 https://www.humanbrainproject.eu/discover/ethics (по состоянию на 20 января 2016).

40 Использование биологического оружия в многих случаях попадает под действие других положений, как например статья 8(2)b) (xx) Римского статута Международного уголовного суда, запрещающей методы и средства войны, которые наносят чрезмерный вред здоровью или приводят к ненужному страданию людей, или по своему характеру неизбирательны, если и когда 
был впервые кодифицирован в 1899 году, считается военным преступлением. $^{41}$ Другой параграф с таким смыслом есть в Женевском протоколе от 1925 года, в котором сказано, что использование вызывающих удушье, отравляющих или других газов и всех «аналогичных жидкостей, материалов или средств» является военным преступлением. Это положение не затрагивает использование бактериологического оружия, которое запрещено Женевским протоколом, и в нем нет дальнейших ссылок ни на химическое, ни на биологическое оружие. Некоторые комментаторы утверждают, что тем не менее биологическое оружие в этом тексте подразумевается - опираясь на предположении, что термин «отравленное оружие» был первым запретом как на химическое, так и на биологическое оружие. ${ }^{42}$ Однако, большинство комментаторов считает, что биологическое оружие не перечислено в Римском статуте. ${ }^{43}$ Отсутствие положения в Римском статуте, которое явным образом определяет использование биологического оружия как военное преступление, является поразительным пропуском в международных законодательных нормах по биологическому оружию и его следует скорейшим образом исправить.

\section{2. Улучшение процедуры КБО по мониторингу науки и технологии на предмет злонамеренного использования}

Развитие науки и технологии порождает необходимость обеспечения адекватности КБО. Происходящие изменения, однако, являются по своему характеру очень техническими и процесс с помощью которого странычлены КБО идентифицируют развитие науки и технологии и оценивают его последствия должен отражать этот факт. Тогда как текущая программа межсессионной работы договора дает ограниченное время и пространство для комплексной оценки изменений в науке и технологии, рассмотрение этих проблем, главным образом в работе по определению политики реализации договора, еще более усложняет эту работу. Необходимо больше времени и другая среда.

Специальный технологический орган, например рабочая группа с открытым составом с председателем и заместителями председателя, назначенная сроком на несколько лет, способствовала бы отделению технических дискуссий от соображений по определению политики. Такая

подписано приложение к этому положению. Смотри Filippa Lentzos and Cecilie Hellestveit, "The Categorical Ban on Bioweapons: Challenged by Synthetic Biology?" in High-Tech War and International Law, ed. Guglielmo Verdirame, et. al. (в печати).

${ }^{41}$ Rome Statute of the International Criminal Court, Article (2)(b)(xvii).

42 Michael Cottier, "War Crimes: Article 5," in Commentary on the Rome Statute of the International Criminal Court, Observers' Notes, Article by Article, ed. Otto Trifferer, $2^{\text {nd }}$ edition (Oxford: Hart Publishing, 2008), 413.

43 Markus Wagner, "The ICC and its Jurisdiction - Myths, Misperceptions and Realities," in Max Planck Yearbook of United Nations Law, vol. 7, ed. Armin von Bogdandy and Rüdiger Wolfrum (Boston: Brill, 2004), 460. 
группа должна работать под руководством эксперта и должна быть инклюзивной, открытой для всех подписантов и для академических институций и других имеющих отношение к этой проблеме организаций, которые могут способствовать коллективным оценкам. Это будет гарантировать, что обсуждения будут касаться только технической стороны проблемы, заключения будут основываться на фактах и рекомендации будут базироваться на прочной научной основе. Очевидными темами для обсуждения являются потенциально пандемические патогены, синтетическая биология и нейробиология, а так же ускорение конвергенции биологии с другими науками, в частности с химией, и последствия всего этого для контроля над вооружениями и для международного права.

Эта группа должна заседать отдельно от Заседания экспертов в рамках реструктурированного межсессионного процесса и должна предоставлять свои рекомендации странам-членам напрямую. Ее нужно обеспечить ресурсами и назначить научного секретаря для оказания непрерывной профессиональной поддержки. Она должна иметь мандат органа Конвенции, осуществляющего функцию мониторинга науки и технологии в соответствие со ст. XII, но на более систематической основе.

\section{3. Усовершенствование норм прозрачности и публичной подотчет- носmu}

Сообщество наук о жизни играет критически важную роль в обеспечении биологического разоружения и нераспространения. Надежное применение КБО зависит от отдельных ученых биологов, от систем и защит в местах, где они работают, от осведомленности о проблемах двойного использования и структурах, поощряющих ответственное поведение, от биобезопасности и бионадежности и всех элементов хороших практик тех, кто принимает участие в развитии соответствующих наук и технологий. Ключом ко всему этому является образование. Не образование в смысле имплантирования фактов и знаний и инструктирования людей, как им думать, а образование в смысле поощрения понимания и обучения людей, как им думать своей головой. Речь идет о том, чтобы создать у биологов чувствительность к рискам злонамеренного использования знаний, полученных в результате их экспериментов и исследований.

Образование, однако, не является конечной целью само по себе; в данном случае, оно скорее должно дать способы влияния на поведение. Конечная цель состоит в том, чтобы люди, занимающиеся науками о жизни, вели себя ответственно, а так же создать слой мониторинга работы, проводимой в их лабораториях и в их областях специализации. Быстрый темп и характер изменений в биологических науках сегодня означает, что все, кроме практикующих ученых биологов, находятся под сильным давлением, направленным на обеспечение современной технической квалификации для осуществления адекватного надзора. Поэтому работа по обеспечению образования и повышению бдительности должна идти рука об руку 
с развитием обеспечивающих структур и профессиональных практик для идентификации любых подозрительных деятельностей и беспокоящих достижений в данной сфере.

Хотя ученые, занимающиеся науками о жизни, могут чувствовать себя независимыми в своей работе, большинство из них подвергаются сильному институциональному и политическому давлению. В академических медицинских центрах, фармацевтических компаниях или государственных институтах, они работают в среде, в которой нормы, профессиональная ответственность и задачи определены бюрократическим способом. Однако, эти научные сообщества так же подчиняются национальным нормам, касающиеся прозрачности и публичной подотчетности. Поэтому подписанты КБО должны следить за национальным применением этого договора в своих государствах, за механизмами, гарантирующими прозрачность и соответствие нормам в межгосударственных отношениях, в качестве средства для утверждения норм прозрачности и публичной подотчетности и за утверждением ответственной науки.

\section{6 авторе}

Филиппа Лентзос, кандидат наук, является старшим научным сотрудником Департамента глобального здоровья и социальной медицины Кингс колледжа в Лондоне. Ее исследования сфокусированы на политических, правовых и связанных с безопасностью аспектах новых технологий в науках о жизни. Скоро выйдут из печати ее книги Biological Threats in the $21^{\text {st }}$ Century (Imperial College Press, 2016) и Synthetic Biology \& Bioweapons (World Scientific, 2016). E-mail: filippa.lentzos@kcl.ac.uk. 